\title{
Identification of angiotensin l-converting enzyme inhibitory peptides from koumiss, a traditional fermented mare's milk
}

\author{
Y. Chen, Z. Wang, X. Chen, Y. Liu, H. Zhang, ${ }^{1}$ and T. Sun ${ }^{1}$ \\ Key Laboratory of Dairy Biotechnology and Engineering, Education Ministry of P. R. China, Department of Food Science and Engineering, \\ Inner Mongolia Agricultural University, Hohhot 010018, P. R. China
}

\begin{abstract}
Angiotensin I-converting enzyme (ACE) inhibitory activities in untreated koumiss and koumiss digested with ACE, pepsin, trypsinase, and chymotrypsin were compared and analyzed. Four novel ACE inhibitory peptides $\left(\mathrm{P}_{\mathrm{I}}, \mathrm{P}_{\mathrm{K}}, \mathrm{P}_{\mathrm{M}}\right.$, and $\left.\mathrm{P}_{\mathrm{P}}\right)$ were purified using ultrafiltration and high performance liquid chromatography (HPLC). The classification study showed that these 4 peptides were of the true inhibitor type. The amino acid sequences of these peptides are YQDPRLGPTGELDPATQPIVAVHNPVIV, PKDLREN, LLLAHLL, and NHRNRMMDHVH, respectively. Their individual $\mathrm{IC}_{50}$ (50\% inhibitory concentration) values were as follows: $14.53 \pm 0.21 \mu M, 9.82 \pm 0.37 \mu M, 5.19 \pm 0.18 \mu M$, and $13.42 \pm 0.17 \mu M$. From sequence analysis, we determined that $P_{I}$ was part of $\beta$-casein in mare's milk. The 3 peptides $\mathrm{P}_{\mathrm{K}}, \mathrm{P}_{\mathrm{M}}$, and $\mathrm{P}_{\mathrm{P}}$ did not correspond with any known milk protein. The results suggest that koumiss is rich in ACE inhibitory peptides, and the ACE inhibitors in koumiss are of the pro-drug type or a mixture of the pro-drug type and the true inhibitor type. These results may provide evidence about the beneficial effects of koumiss, especially on cardiovascular health.
\end{abstract}

Key words: angiotensin I-converting enzyme, koumiss, peptide, angiotensin I-converting enzyme inhibitors

\section{INTRODUCTION}

Angiotensin I-converting enzyme (ACE; EC 3.4.15.1) is a nonspecific but highly selective key multifunctional ectoenzyme that is involved in the regulation of peripheral blood pressure (Studdy et al., 1983). Angiotensin I-converting enzyme catalyzes the release of the dipeptide His-Leu from the angiotensin I C-terminus, which results in the production of the octapeptide angiotensin II, a potent vasoconstrictor (Riordan, 2003). The enzyme also hydrolyzes and inactivates the vasoactive bradykinin (Centeno et al., 2006). Additionally, ACE is

\footnotetext{
Received August 25, 2009.

Accepted November 27, 2009.

${ }^{1}$ Corresponding authors: hepingdd@vip.sina.com and sts9940@sina. com
}

a stimulant for the release of aldosterone in the adrenal cortex (Cushman et al., 1977; Cheung et al., 1980). As a result, ACE inhibitors have been shown to reduce peripheral blood pressure and exert an antihypertensive effect in vivo. A myriad of food protein sources including fish, gelatin, maize, soy, and milk proteins have been reported to contain bioactive peptide sequences (Geerlings et al., 2006; López-Fandiňoa et al., 2006).

Koumiss (Kumis, Kymyz, or Qymyz) is a traditional fermented milk product originating in the Central Asian steppes and is mostly produced from mare's milk (Ozer, 2000; Di Cagno et al., 2004). Its production and consumption has a long history in Eastern Europe and Central Asian countries. Koumiss is produced by 2 major fermentations: lactic acid fermentation and alcohol fermentation. Adjusting the ratio of these 2 oxidation reactions through fermenting temperature is considered to be a key factor for koumiss manufacture. The fermenting temperature is 25 to $26^{\circ} \mathrm{C}$ in summer, but 28 to $30^{\circ} \mathrm{C}$ in winter.

The composition of mare's milk is significantly different from that of bovine milk and is similar to that of human milk. The amino acid composition of its protein is also closer to that of human breast milk than to bovine or caprine milk. In addition, mare's milk is rich in nonprotein nitrogen (Malacarne et al., 2002). Because of its excellent nutritional value and easy digestibility, mare's milk and its fermented products (i.e., koumiss and cheese) are widely used in Eurasia (e.g., Russia, and Mongolia; Marconi and Panfili, 1998). In Western Europe, more research is being focused on the use of mare's milk for human consumption (Csapo-Kiss et al., 1995).

The Mongolian lifestyle is mainly nomadic, and Mongolians have discovered the many specialty and therapeutic characteristics of koumiss by historical practice. In previous studies, it was reported that koumiss could improve the body's alimentary canal, metabolism, circulatory, and nervous systems, blood-forming organs, functions of kidneys, endocrine glands, and the immune system. Koumiss is considered an effective remedy when treating pulmonary tuberculosis, tuberculosis of the urogenital system, exhaustion, and anemia (Wang 
et al., 2008). Russia, Mongolia, and Inner Mongolia of China established "koumiss sanatoria" mainly for the treatment of chronic consumption diseases such as angiocardiopathy and pulmonary tuberculosis (Yuan et al., 2006).

In this study, the variation of ACE inhibitory activities in koumiss samples digested by ACE, pepsin, trypsinase, and chymotrypsin was analyzed. Additionally, peptides with ACE inhibitory activities from koumiss were extracted, purified, and analyzed. The results of this study may provide data for determining the potential application of koumiss as a component of antihypertensive functional foods.

\section{MATERIALS AND METHODS}

\section{Materials}

Koumiss samples were collected from a koumiss sanatorium in the Xilingole region of Inner Mongolia, China. Hippuryl-L-histidyl-L-leucine (HHL), hippuric acid, $o$-phthaldialdehyde, SDS, $\beta$-mercaptoethanol, ACE $(1.0 \mathrm{U} / \mathrm{g})$, pepsin (EC 3.4.23.1; 3,800 U/mg), trypsinase (EC 3.4.21.4; 1,000 U/mg), and $\alpha$-chymotrypsin (EC 3.4.21.1; 1,200 U/g) were purchased from Sigma Chemical Co. (St. Louis, MO).

\section{Chemical Analysis}

Fat, ash, and total protein contents and titratable acidity of koumiss were determined following standard methods (AOAC, 1997). Calcium was determined by EDTA titration (Qi, 1986). The determination of total phosphorus was performed by using the molybdenumblue colorimetric method. Ethanol content was quantified by the chemical oxidation method after microdistillation of the koumiss samples, which was performed by Ethanol (Äthanol) kit (Boehringer Mannheim/RBiopharm Company, Darmstadt, Germany). The concentrations of lactose, vitamin $\mathrm{C}$, and lactic acid were determined by HPLC according to the methods of Lamoureux et al. (2002), Wu et al. (1996), and Mullin and Emmons (1997), respectively.

Peptide concentration was measured using the method described by Church et al. (1983) with some modifications. The reagent was prepared by mixing 125 $\mathrm{mL}$ of $100 \mathrm{~m} M$ borax, $25 \mathrm{~mL}$ of $10 \%$ (wt/wt) SDS, 200 $\mathrm{mg}$ of $o$-phthaldialdehyde solution (dissolved in $5 \mathrm{~mL}$ of methanol), and $500 \mu \mathrm{L}$ of $\beta$-mercaptoethanol, and then adjusting the volume to $250 \mathrm{~mL}$ using deionized water. Fifty microliters of the sample was mixed with $2 \mathrm{~mL}$ of reagent. The reaction mixture was incubated at room temperature for $2 \mathrm{~min}$, and the absorbance was measured at $340 \mathrm{~nm}$ with a spectrophotometer (UV-1700,
Shimadzu, Tokyo, Japan). The peptide content was quantified using casein tryptone (Difco Laboratories, Sparks, MD) as the standard.

\section{Microbiological Analysis}

The counts of various microbial populations (cfu/ $\mathrm{mL}$ ) in these samples were enumerated using the methods described by Ishii (2003). Serial dilutions were prepared, and lactic acid bacteria (LAB) and yeast counts were enumerated using plate count agar with bromo-cresol purple and cycloheximide (Eiken Chemical Co. Ltd., Tokyo, Japan) and potato dextrose agar (Eiken Chemical Co. Ltd.), respectively. Coliforms were enumerated using the most probable number (MPN) method described by the AOAC (1997).

\section{ACE Inhibitory Activity In Vitro}

The ACE inhibitory activity was measured using the HPLC method described by Mao et al. (2007) with some modifications. Hippuryl-L-histidyl-L-leucine and ACE were dissolved separately in $100 \mathrm{mM}$ Na-borate buffer ( $\mathrm{pH} 8.3$ ) containing $300 \mathrm{mM} \mathrm{NaCl}$. A mixture containing $40 \mu \mathrm{L}$ of sample and $40 \mu \mathrm{L}$ of HHL (10 $\mathrm{m} M)$ solution was incubated at $37^{\circ} \mathrm{C}$ for 2 min. Forty microliters of ACE $(0.010 \mathrm{U} / \mathrm{mL})$ solution was added, and the mixture was incubated at $37^{\circ} \mathrm{C}$ for $30 \mathrm{~min}$. The reaction was stopped by heating the mixture in a boiling-water bath for $10 \mathrm{~min}$ to inactivate the enzyme. Afterward, $180 \mu \mathrm{L}$ of deionized water was added, and $20 \mu \mathrm{L}$ of this solution was directly injected onto a Zorbax $\mathrm{C}_{18}$ column $(4.6 \times 250 \mathrm{~mm}$, particle size $5 \mu \mathrm{m}$, Agilent, Santa Clara, CA) to separate the product and hippuric acid from HHL. The column was eluted with $75 \%$ acetonitrile in water ( $\mathrm{vol} / \mathrm{vol})$ containing $0.1 \%$ trifluoroacetic acid (TFA) at a flow rate of $1.5 \mathrm{~mL} / \mathrm{min}$ using a pump, and the eluant was monitored at $228 \mathrm{~nm}$. The column temperature was controlled at $30^{\circ} \mathrm{C}$.

The inhibition was calculated from the following equation:

$$
\begin{gathered}
\text { ACE inhibitory activity }= \\
{[(\mathrm{Cc}-\mathrm{Cs}) /(\mathrm{Cc}-\mathrm{Cb})] \times 100 \%}
\end{gathered}
$$

where $\mathrm{Cc}$ was the concentration of the buffer (control), Cs was the concentration of the reaction mixture (sample), and $\mathrm{Cb}$ was the concentration of the blank samples with adding solution before the reaction. The concentration $(\mathrm{mg} / \mathrm{mL}$ or $\mu M)$ that inhibited $50 \%$ of $\mathrm{ACE}$ activity $\left(\mathbf{I C}_{50}\right)$ was determined by regression analysis of ACE inhibition (\%) versus peptide concentration in duplicate. 


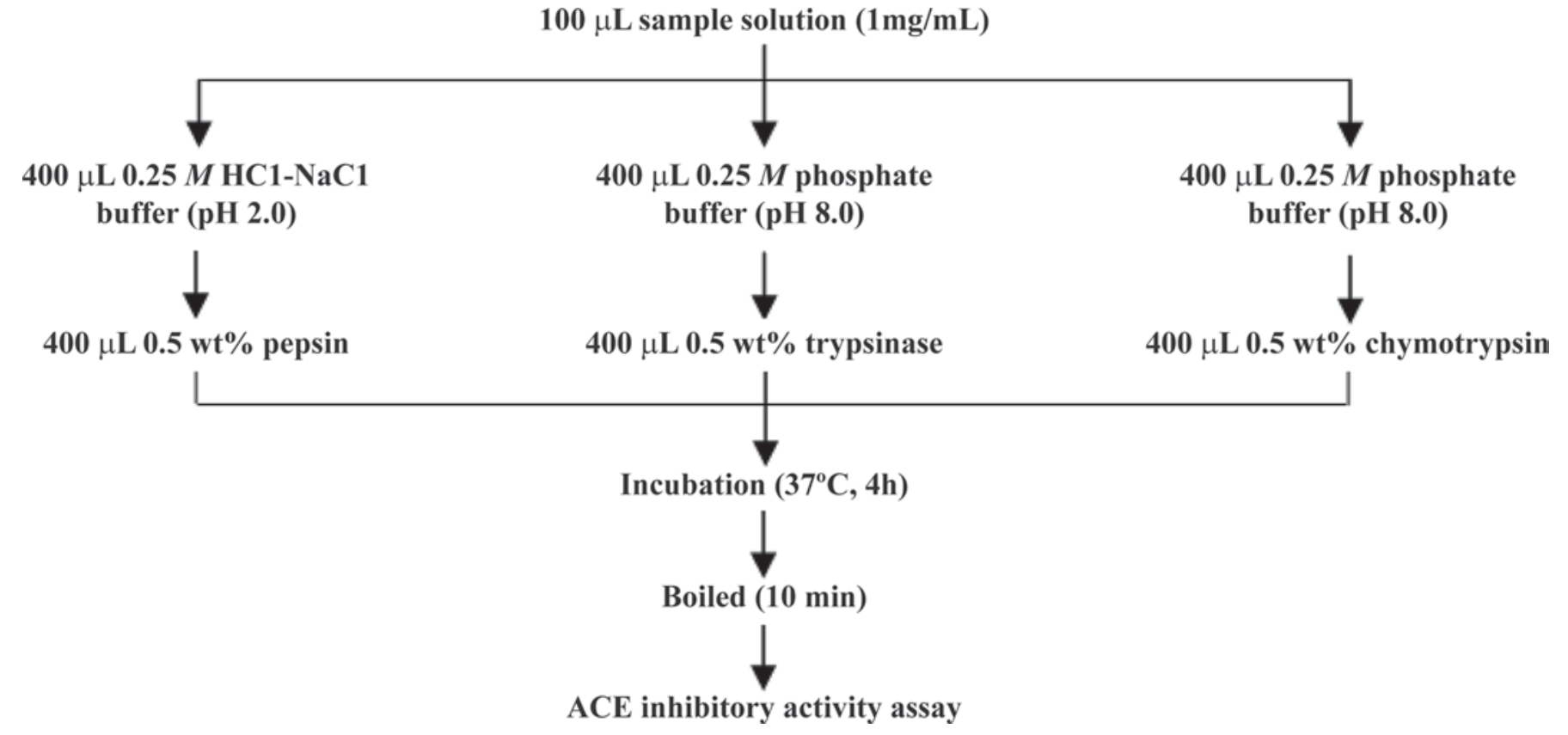

Figure 1. The procedure of koumiss digestion by gastrointestinal protease and angiotensin I-converting enzyme (ACE) inhibitory activity determination.

\section{Classification of Koumiss by Incubation Method}

The stability of koumiss to ACE was determined using the method described by Fujita et al. (2000). The samples were diluted to $200 \mathrm{mg} / \mathrm{mL}$, and $100 \mu \mathrm{L}$ of the diluted sample was added to $100 \mu \mathrm{L}$ of ACE solution $(0.020 \mathrm{U} / \mathrm{mL})$. The mixture was incubated at $37^{\circ} \mathrm{C}$ for $4 \mathrm{~h}$, and the reaction was stopped by boiling for $10 \mathrm{~min}$. After cooling, the ACE inhibitory activity was assayed. The procedure of koumiss digestion by gastrointestinal proteases and analysis of ACE inhibitory activity assaying were performed using the methods of Zhang et al. (2006) as shown in Figure 1.

\section{Purification of ACE Inhibitory Peptides}

Preparation and Ultrafiltration of Koumiss Whey. Koumiss was heated at $85^{\circ} \mathrm{C}$ for $10 \mathrm{~min}$ to inactivate the proteases and LAB. Then, the samples were quickly cooled to $4^{\circ} \mathrm{C}$. The samples were centrifuged $\left(10,000 \times g, 10 \mathrm{~min}, 4^{\circ} \mathrm{C}\right)$ and the supernatant fluid was collected.

To purify the ACE inhibitory peptides, the active koumiss whey was passed through a polyether-sulfone ultrafiltration membrane with 10- and 3-kDa molecular weight (MW) cut-off membranes (Millipore Co., Billerica, MA) in succession. The whey was separated into 3 fractions: $>10 \mathrm{kDa}, 3$ to $10 \mathrm{kDa}$, and $<3 \mathrm{kDa}$. The 3 fractions were lyophilized and analyzed for peptide concentration and ACE inhibitory activity using the method described above, respectively. The most active fraction was used for further separation by HPLC.

HPLC Separation. Semipreparative reverse phaseHPLC separations were performed on an Agilent 1100 Series LC system. A preparative Zorbax $\mathrm{C}_{18}$ column $(9.4 \times 250 \mathrm{~mm}$ i.d., $5-\mu \mathrm{m}$ particle size, $80 \AA$ pore size, Agilent) was used. Solvent A was $0.1 \%$ (vol/vol) TFA diluted in deionized water, and solvent $\mathrm{B}$ was $0.1 \%$ (vol/vol) TFA diluted in acetonitrile $\left(\mathrm{CH}_{3} \mathrm{CN}\right)$ solution. Elution was performed with a linear gradient as follows: solvent B 5 to $10 \%$ in $20 \mathrm{~min}, 10$ to $20 \%$ in $40 \mathrm{~min}, 5$ to $10 \%$ in $20 \mathrm{~min}$. Column temperature was $30^{\circ} \mathrm{C}$, and the flow rate was $2.8 \mathrm{~mL} / \mathrm{min}$. Absorbance of the eluant at $220 \mathrm{~nm}$ was monitored. Sample concentration of fraction I from koumiss was $250 \mathrm{mg} / \mathrm{mL}$ and the injection volume was $1.0 \mathrm{~mL}$. The fractions from the HPLC system were collected, freeze-dried, and kept at $-20^{\circ} \mathrm{C}$ until use. Peptide concentration and in vitro ACE inhibitory activity were determined for each fraction.

The fraction that exhibited the highest ACE inhibitory activity was subjected to chromatography again through an analytical Zorbax $\mathrm{C}_{18}$ column $(4.6 \mathrm{~mm} \times$ $250 \mathrm{~mm}$ i.d., $5-\mu \mathrm{m}$ particle size, $80 \AA$ pore size, Agilent) using a binary gradient with acetonitrile as an organic modifier. The flow rate was adjusted to $0.8 \mathrm{~mL} / \mathrm{min}$, and the column temperature and preparation of solvents A and B were as the same as described above. Peaks at $220 \mathrm{~nm}$ were detected by UV detector. The active frac- 
Table 1. Chemical analysis of koumiss $(\mathrm{n}=5$, mean \pm SD)

\begin{tabular}{lr}
\hline Item & \multicolumn{1}{c}{ Content } \\
\hline Fat $(\mathrm{g} / 100 \mathrm{~g})$ & $1.97 \pm 0.43$ \\
Total protein $(\mathrm{g} / 100 \mathrm{~g})$ & $2.26 \pm 0.48$ \\
Lactose $(\mathrm{g} / 100 \mathrm{~g})$ & $2.58 \pm 0.41$ \\
Ethanol $(\mathrm{g} / \mathrm{L})$ & $13.11 \pm 0.68$ \\
Ash $(\mathrm{g} / 100 \mathrm{~g})$ & $0.30 \pm 0.06$ \\
Lactic acid $(\mathrm{g} / 100 \mathrm{~g})$ & $8.52 \pm 0.54$ \\
Titratable acidity $\left({ }^{\circ} \mathrm{T}\right)$ & $98.63 \pm 3.25$ \\
Calcium $(\mathrm{mg} / 100 \mathrm{~g})$ & $78.49 \pm 1.55$ \\
Phosphorus $(\mathrm{mg} / 100 \mathrm{~g})$ & $55.63 \pm 0.69$ \\
Vitamin C $(\mathrm{mg} / 100 \mathrm{~g})$ & $5.55 \pm 0.24$ \\
\hline
\end{tabular}

tions were collected again and lyophilized immediately. The active fractions collected above were used for ACE inhibitory peptide identification and stability analysis.

\section{Identification of ACE Inhibitory Peptides}

The amino acid composition of the peptides were analyzed using matrix-assisted laser desorption timeof-flight/time-of-flight mass spectrometry (Ultraflex, Bruker Daltonics Inc., Billerica, MA), Biotools 2.0 and Peaks 4.5 (Bruker Daltonics, Bremen, Germany). The identification of ACE inhibitory peptides was completed by the National Center of Biomedical Analysis (Beijing, China).

\section{Stability of ACE Inhibitory Peptides Derived from Koumiss}

The ACE inhibitory peptides derived from koumiss were dissolved in distilled water and subsequently incubated at various temperatures $(40,60,80$, and $100^{\circ} \mathrm{C}$ ) for $2 \mathrm{~h}$. After the samples were cooled to room temperature, their $\mathrm{pH}$ was adjusted to 8.3. The ACE inhibitory activity was then measured.

For the $\mathrm{pH}$ stability test, samples were dissolved in distilled water and then adjusted to various $\mathrm{pH}$ values $\left(2,4,6,8\right.$, and 10). The samples were incubated at $37^{\circ} \mathrm{C}$ for $2 \mathrm{~h}$, and then cooled to room temperature. Finally, the $\mathrm{pH}$ value was adjusted to 8.3 and the ACE inhibitory activity of each peptide was measured as described earlier. One hundred microliters of the peptide sample was mixed with $100 \mu \mathrm{L}$ of ACE solution $(0.020 \mathrm{U} / \mathrm{mL})$, and the mixture was incubated at $37^{\circ} \mathrm{C}$ for $4 \mathrm{~h}$. The reaction was stopped by boiling for $10 \mathrm{~min}$. After cooling, ACE inhibitory activity was assayed.

\section{Statistical Analysis}

Experimental data were analyzed by using ANOVA, and significance was tested by using SAS software (SAS version 9.00, SAS Institute Inc. Cary, NC). The chemical composition of each sample was tested 3 times, and the results were expressed as means \pm standard deviation. The microbiology counts were indicated as base 10 logarithm of the microbe count contained per milliliter of traditional fermented milk ( $\log \mathrm{cfu} / \mathrm{mL}$ ).

\section{RESULTS AND DISCUSSION}

\section{Chemical Analysis}

Chemical analyses of the samples are presented in Table 1. The fat, total protein, lactose, lactic acid, titratable acidity, and calcium and phosphorus contents in Xilinguole samples are slightly higher compared with those in the koumiss samples of Xinjiang, as reported by Sun et al. (2005). This may be because of differences of sampling region, horse varieties, lactation period, and fermenting procedure. From the parallel value of the chemical composition of koumiss samples, we can conclude that the koumiss and its manufacture in the sanatorium were stable.

\section{Microbiological Analysis}

Table 2 shows the average counts of LAB, yeasts, and coliforms (MPN) in the samples we collected. High mean counts of LAB $(7.86 \pm 0.86 \log \mathrm{cfu} / \mathrm{mL})$ and yeasts $(6.48 \pm 0.71 \log \mathrm{cfu} / \mathrm{mL})$ were observed. The LAB counts were greater than those of yeast by almost 1 log-cycle; conversely, MPN was 2.

The MPN of coliforms may be considered as an indicator of fecal contamination and contamination by other enteric pathogens. The MPN of coliforms (see Table 2) in all koumiss samples was much lower than $90 \mathrm{MPN} / 100 \mathrm{~mL}$, which was within the National Standard of People's Republic of China for Yogurt (GB 2746-1999; Guo, 2003). These results proved that the koumiss samples were microbiologically safe.

Table 2. Microbiological analysis of koumiss $(\mathrm{n}=5$, mean $\pm \mathrm{SD})$

\begin{tabular}{lcc}
\hline Item & Mean $\pm \mathrm{SD}$ & Range \\
\hline Lactic acid bacteria $(\log \mathrm{cfu} / \mathrm{mL})$ & $7.86 \pm 0.86$ & $7.03-8.28$ \\
Yeast $(\log \mathrm{cfu} / \mathrm{mL})$ & $6.48 \pm 0.71$ & $6.08-7.15$ \\
Coliforms $\left(\mathrm{MPN}^{1}\right)$ & 2 & $0-3$ \\
\hline
\end{tabular}

${ }^{1} \mathrm{MPN}=$ most probable number. 
Table 3. The $50 \%$ inhibitory concentration $\left(\mathrm{IC}_{50}\right.$ value; $\mathrm{mg} / \mathrm{mL}$ ) of koumiss incubated with various enzymes

\begin{tabular}{|c|c|c|c|c|c|}
\hline \multirow[b]{2}{*}{ Sample } & \multicolumn{5}{|c|}{ Koumiss-enzyme combination $^{1}$} \\
\hline & Koumiss & $\mathrm{K}-\mathrm{ACE}$ & $\mathrm{K}-\mathrm{P}$ & $\mathrm{K}-\mathrm{T}$ & $\mathrm{K}-\mathrm{C}$ \\
\hline $\mathrm{IC}_{50}$ value $(\mathrm{mg} / \mathrm{mL})$ & $52.47 \pm 2.87^{\mathrm{a}}$ & $55.57 \pm 2.22^{\mathrm{a}}$ & $26.77 \pm 1.19^{\mathrm{c}}$ & $42.73 \pm 1.45^{\mathrm{c}}$ & $37.43 \pm 2.75^{\mathrm{c}}$ \\
\hline
\end{tabular}

\section{Classification of ACE Inhibitors in Koumiss by Different Incubation Methods}

Table 3 shows the ACE inhibitory activity of untreated samples and samples treated with ACE, pepsin, trypsinase, and chymotrypsin. The $\mathrm{IC}_{50}$ value of koumiss increased from $52.5 \pm 2.9$ to $55.6 \pm 3.2 \mathrm{mg} /$ $\mathrm{mL}$ after koumiss was incubated with $\mathrm{ACE}$, but the difference was not significant $(P>0.05)$.

To investigate the resistance of the inhibitors from the koumiss to gastrointestinal proteases, the samples were digested with pepsin, trypsinase, and chymotrypsin. All the $\mathrm{IC}_{50}$ values of the koumiss hydrolyzed by gastrointestinal proteases were significantly $(P<0.01)$ lower than that of untreated samples. The highest $\mathrm{IC}_{50}$ value $(42.7 \pm 1.5 \mathrm{mg} / \mathrm{mL})$ of the hydrolyzed samples was obtained after treatment with trypsinase, with $18.6 \%$ of the untreated samples lost. The lowest $\mathrm{IC}_{50}$ value ( 34.8 $\pm 2.3 \mathrm{mg} / \mathrm{mL}$ ) was observed when the samples were hydrolyzed by pepsin. The result indicated that the ACE inhibitory peptides could be released by digestion and could maintain their active form even after gastric digestion.

According to Fujita et al., (2000), ACE inhibitory peptides in vitro can be classified into 3 groups: 1 ) true inhibitor type, with $\mathrm{IC}_{50}$ values of peptides that are not affected by preincubation with ACE or gastrointestinal proteases; 2) substrate type, with peptides that are converted to true inhibitors by ACE or gastrointestinal proteases, resulting in peptides with weaker activity; and 3) pro-drug type, with peptides that are converted to true inhibitors by ACE or gastrointestinal proteases. Our results indicated that the ACE inhibitors in koumiss were of the pro-drug type or a mixture of the pro-drug type and the true inhibitor type.

\section{Ultrafiltration}

After separation by 10 - and 3-kDa MW cut-off membranes, 3 fractions of ACE were obtained: fraction I $(>10 \mathrm{kDa})$, fraction II $(10-3 \mathrm{kDa})$, and fraction III $(<3$ $\mathrm{kDa}$ ). From Table 4, we can conclude that the most active fraction was that with $\mathrm{MW}<3 \mathrm{kDa}$ (fraction III).

Table 4 shows that the $\mathrm{IC}_{50}$ of fraction III powder $(80.11 \pm 2.13 \mathrm{mg} / \mathrm{mL})$ was significantly lower $(P<$ $0.01)$ than that of fractions I $(>100 \mathrm{mg} / \mathrm{mL})$ and II $(>100 \mathrm{mg} / \mathrm{mL})$. However, it was higher $(P<0.01)$ than that of koumiss $(52.47 \pm 2.87 \mathrm{mg} / \mathrm{mL})$. Because fraction III contains a large amount of non-ACE inhibitory components (lactic acid, lactose, and amino acids), its $\mathrm{IC}_{50}$ was higher than that of koumiss whey. The ACE inhibitory efficiency ratio (IER) of fraction III (225.7 \pm $2.8 \%$ per $\mathrm{mg} / \mathrm{mL})$ was significantly higher $(P<0.01)$ than that of koumiss and other fractions. It indicated that fraction III could be considered a major ACE inhibitor of koumiss whey. From the results obtained above, we also conclude that the ultrafiltration method can concentrate ACE inhibitors derived from koumiss.

It was shown that lower MW fraction of the koumiss whey can express a higher ACE inhibitory activity. Moreover, most of the effective fragments were contained in fraction III. The results were similar to those

Table 4. The angiotensin I-converting enzyme (ACE) inhibitory activity (\%), ACE inhibitory efficiency ratio (IER; \% per $\mathrm{mg} / \mathrm{mL})$, peptide concentration $(\mathrm{mg} / \mathrm{mL})$, and $50 \%$ inhibitory concentration $\left(\mathrm{IC}_{50} ; \mathrm{mg} / \mathrm{mL}\right)$ of koumiss and fractions by ultrafiltration through 10- and 3-kDa molecular weight cut-off membranes

\begin{tabular}{lcccc}
\hline Fraction $^{1}$ & $\begin{array}{c}\text { ACE inhibitory } \\
\text { activity }(\%)\end{array}$ & $\begin{array}{c}\text { Peptide concentration } \\
(\mathrm{mg} / \mathrm{mL})\end{array}$ & IER $(\%$ per $\mathrm{mg} / \mathrm{mL})$ & $\mathrm{IC}_{50}(\mathrm{mg} / \mathrm{mL})$ \\
\hline Koumiss & $65.77 \pm 1.02^{\mathrm{a}}$ & $0.321 \pm 0.010^{\mathrm{c}}$ & $204.9 \pm 3.2^{\mathrm{a}}$ & $52.47 \pm 2.87^{\mathrm{b}}$ \\
I & $30.59 \pm 1.13^{\mathrm{c}}$ & $0.539 \pm 0.013^{\mathrm{a}}$ & $56.8 \pm 2.1^{\mathrm{d}}$ & $>100$ \\
II & $33.25 \pm 1.55^{\mathrm{c}}$ & $0.339 \pm 0.004^{\mathrm{b}}$ & $98.1 \pm 4.6^{\mathrm{c}}$ & $>100$ \\
III & $55.29 \pm 3.76^{\mathrm{b}}$ & $0.245 \pm 0.003^{\mathrm{d}}$ & $225.7 \pm 2.8^{\mathrm{a}}$ & $80.11 \pm 2.13^{\mathrm{a}}$ \\
\hline
\end{tabular}

${ }^{a-d}$ Means bearing different letters in the same column differ significantly compared with koumiss $(P<0.05)$.

${ }^{1}$ Fraction I: molecular weight $(\mathrm{MW})>10 \mathrm{kDa}$; fraction II: $10 \mathrm{kDa}>\mathrm{MW}>3 \mathrm{kDa}$; fraction III: $<3 \mathrm{kDa}$. 
Table 5. The angiotensin I-converting enzyme (ACE) inhibitory activity (\%), peptide concentration (mg/ $\mathrm{mL}$ ), and ACE inhibitory efficiency ratio (IER; \% per $\mathrm{mg} / \mathrm{mL}$ ) of reverse phase-HPLC of fraction III separated from koumiss

\begin{tabular}{lccc}
\hline Fraction & $\begin{array}{c}\text { ACE inhibitory } \\
\text { activity }(\%)\end{array}$ & $\begin{array}{c}\text { Peptide concentration } \\
(\mathrm{mg} / \mathrm{mL})\end{array}$ & $\begin{array}{c}\text { IER }(\% \text { per } \\
\mathrm{mg} / \mathrm{mL})\end{array}$ \\
\hline $\mathrm{A}$ & $68.39 \pm 1.67$ & $12.083 \pm 0.007$ & $5.8 \pm 0.21$ \\
$\mathrm{~B}$ & $46.59 \pm 6.24$ & $0.893 \pm 0.006$ & $52.3 \pm 4.40$ \\
$\mathrm{C}$ & $41.61 \pm 2.75$ & $9.619 \pm 0.042$ & $4.4 \pm 0.33$ \\
$\mathrm{D}$ & $86.67 \pm 0.72$ & $1.975 \pm 0.001$ & $43.9 \pm 0.41$ \\
$\mathrm{E}$ & $42.98 \pm 0.89$ & $2.340 \pm 0.006$ & $18.4 \pm 0.46$ \\
$\mathrm{~F}$ & $74.20 \pm 1.21$ & $19.587 \pm 0.049$ & $3.9 \pm 0.12$ \\
$\mathrm{G}$ & $82.67 \pm 6.05$ & $1.286 \pm 0.014$ & $64.3 \pm 4.73$ \\
$\mathrm{H}$ & $48.24 \pm 2.85$ & $6.810 \pm 0.039$ & $7.2 \pm 0.48$ \\
$\mathrm{P}_{\mathrm{I}}$ & $89.70 \pm 3.01$ & $0.203 \pm 0.004$ & $441.87 \pm 14.87$ \\
$\mathrm{~J}$ & $97.02 \pm 3.33$ & $0.370 \pm 0.006$ & $262.0 \pm 9.01$ \\
$\mathrm{P}_{\mathrm{K}}$ & $67.76 \pm 9.88$ & $0.069 \pm 0.005$ & $980.2 \pm 142.90$ \\
$\mathrm{~L}$ & $67.92 \pm 1.73$ & $0.438 \pm 0.001$ & $155.0 \pm 4.04$ \\
$\mathrm{P}_{\mathrm{M}}$ & $88.16 \pm 0.89$ & $0.242 \pm 0.001$ & $377.9 \pm 10.72$ \\
$\mathrm{~N}$ & $91.61 \pm 1.44$ & & \\
$\mathrm{O}$ & $38.04 \pm 3.74$ & $0.138 \pm 0.009$ & -132 \\
$\mathrm{P}_{\mathrm{P}}$ & $74.56 \pm 2.54$ & $0.832 \pm 0.010$ & $540.3 \pm 18.41$ \\
$\mathrm{Q}$ & $44.12 \pm 0.24$ & $0.079 \pm 0.008$ & $53.3 \pm 0.30$ \\
$\mathrm{R}$ & $21.41 \pm 2.77$ & $0.089 \pm 0.007$ & $270.6 \pm 35.08$ \\
$\mathrm{~S}$ & $36.08 \pm 0.49$ & $0.060 \pm 0.004$ & $302.8 \pm 5.49$ \\
$\mathrm{~T}$ & $20.65 \pm 0.57$ & $0.440 \pm 0.024$ & $344.2 \pm 9.58$ \\
$\mathrm{U}$ & $39.94 \pm 1.54$ & & $90.78 \pm 3.45$ \\
\hline
\end{tabular}

of Ana et al. (2007). They identified novel antihypertensive peptides in milk fermented with Enterococcus faecalis and found that the highest ACE inhibitory activity was expressed by the ultrafiltration fractions with $\mathrm{MW}<3 \mathrm{kDa}$.

\section{Reverse Phase-HPLC Separation of the Active Fraction}

Fraction III, with the highest ACE inhibitory activity, was used for further reverse phase-HPLC separation through a $\mathrm{C}_{18}$ column. Twenty-one fractions were collected manually. The ACE inhibitory activity and peptide concentration of these 21 fractions are shown in Table 5.

These results indicated that fraction III had the highest ACE inhibitory activity composition. Four single compounds with retention times of $34.3 \mathrm{~min}\left(\mathbf{P}_{\mathbf{I}}\right), 40.7$ $\min \left(\mathbf{P}_{\mathbf{K}}\right), 43.2 \min \left(\mathbf{P}_{\mathbf{M}}\right)$, and $47.8 \min \left(\mathbf{P}_{\mathbf{P}}\right)$ displayed the strongest ACE inhibitory activity. The ACE IER of fractions $\mathrm{P}_{\mathrm{I}}, \mathrm{P}_{\mathrm{K}}, \mathrm{P}_{\mathrm{M}}$, and $\mathrm{P}_{\mathrm{P}}$ were $441.87 \pm 14.87,980.2$ $\pm 142.90,1,055.8 \pm 10.72$, and $540.3 \pm 18.41 \mathrm{mg} / \mathrm{L}$, respectively (Table 5).

\section{Molecular Weight and Amino Acid Sequences of ACE Inhibitory Peptides}

The fractions were identified after purification by analytical reverse phase-HPLC. The MW of the purified ACE inhibitory peptides $\mathrm{P}_{\mathrm{I}}, \mathrm{P}_{\mathrm{K}}, \mathrm{P}_{\mathrm{M}}$, and $\mathrm{P}_{\mathrm{P}}$ from koumiss were estimated to be $2,995.6,792.6,871.5$, and
1,460.7 Da, respectively. Their amino acid sequences were YQDPRLGPTGELDPATQPIVAVHNPVIV, PKDLREN, LLLAHLL, and NHRNRMMDHVH, respectively, as detected by matrix-assisted laser desorption time-of-flight/time-of-flight mass spectrometry. Their $\mathrm{IC}_{50}$ values were $43.52 \pm 0.61,7.78 \pm 0.29,4.52$ \pm 0.15 , and $19.60 \pm 0.25 \mathrm{mg} / \mathrm{L}$, respectively (Table 6), and significant differences existed among them.

We compared the sequences of these 4 peptides obtained from koumiss using software Biotools 2.0 and Peaks 4.5 (Table 6). From the results, we can see that only peptide $\mathrm{P}_{\mathrm{I}}$ was a peptide from mare's milk ( $\beta$-casein: f213-241). The peptide $\mathrm{P}_{\mathrm{K}}$ expressed $100.00 \%$ identity with the sequence of f144-150 in cytochrome c-type protein NrfB (YP_001344013; National Center for Biotechnology Information, NCBI) of Actinobacillus succinogenes $130 \mathrm{Z}$. Actinobacillus succinogenes $130 \mathrm{Z}$ can ferment glucose to major products like succinate, acetate, and formate, but there was no known report on the function of the cytochrome c-type protein NrfB protein. Moreover, microbiological analysis of koumiss is focused on lactobacilli and yeasts, because these 2 species are important for koumiss fermentation. There are no reports on the existence of Actinobacillus succinogenes, but koumiss is a spontaneously fermented dairy product and it should have an abundant microbial biodiversity.

For the other 2 peptides $\left(\mathrm{P}_{\mathrm{M}}\right.$ and $\left.\mathrm{P}_{\mathrm{P}}\right)$, we did not find any milk protein/peptide origins that coincided with the sequences reported in the NCBI database (http:// www.ncbi.nlm.nih.gov). Similar to peptide $\mathrm{P}_{\mathrm{K}}$, these 2 
Table 6. The molecular weight (MW), $50 \%$ inhibitory concentration $\left(\mathrm{IC}_{50} ; \mathrm{mg} / \mathrm{L}\right.$ and $\left.\mu M\right)$, and origin of angiotensin I-converting enzyme inhibitory peptides $\mathrm{P}_{\mathrm{I}}, \mathrm{P}_{\mathrm{K}}, \mathrm{P}_{\mathrm{M}}$, and $\mathrm{P}_{\mathrm{P}}$ derived from koumiss

\begin{tabular}{|c|c|c|c|c|}
\hline \multirow[b]{2}{*}{ Item } & \multicolumn{4}{|c|}{ Peptide } \\
\hline & $\mathrm{P}_{\mathrm{I}}$ & $\mathrm{P}_{\mathrm{K}}$ & $\mathrm{P}_{\mathrm{M}}$ & $\mathrm{P}_{\mathrm{P}}$ \\
\hline MW (Da) & $2,995.5$ & 792.6 & 871.5 & $1,460.7$ \\
\hline $\mathrm{IC}_{50}$ value $(\mathrm{mg} / \mathrm{L})$ & $43.52 \pm 0.61^{\mathrm{a}}$ & $7.78 \pm 0.29^{\mathrm{c}}$ & $4.52 \pm 0.15^{\mathrm{d}}$ & $19.60 \pm 0.25^{\mathrm{b}}$ \\
\hline $\mathrm{IC}_{50}$ value $(\mu M)$ & $14.53 \pm 0.21^{\mathrm{a}}$ & $9.82 \pm 0.37^{\mathrm{c}}$ & $5.19 \pm 0.18^{\mathrm{d}}$ & $13.42 \pm 0.17^{\mathrm{b}}$ \\
\hline Origin & $\beta$-casein (f213-241) & $\mathrm{CPN}^{1}(\mathrm{f} 144-150)$ & Unknown & Unknown \\
\hline
\end{tabular}

peptides may be from the microorganisms existing in koumiss. In further studies, we will attempt to determine their effects during koumiss processing and their possible role in the therapeutic function of koumiss.

\section{Stability of ACE Inhibitory Peptides Derived from Koumiss}

With the current interest in preparing foods possessing functional ingredients, it is important to test the stability of functional components during and after processing. As shown in Figure 2, the peptides could sustain their ACE inhibitory activity after various temperature, $\mathrm{pH}$, and $\mathrm{ACE}$ treatments. The ACE inhibitory activity of peptides derived from koumiss showed little change after treatment at various temperatures. Figure 2 showed that these peptides had good thermal stability.

These peptides expressed different changes after treatment at various $\mathrm{pH}$ values. From the results, we can see that peptide $\mathrm{P}_{\mathrm{M}}$ showed the highest stability under various $\mathrm{pH}$ treatments. For the other 3 peptides, more than $95 \%$ ACE inhibitory activity was retained at $\mathrm{pH} 4, \mathrm{pH} 6$, and $\mathrm{pH}$ 8. However, the activity of these peptides declined significantly $(P<0.01)$ at $\mathrm{pH} 2.0$. The $\mathrm{IC}_{50}$ value of peptides $\mathrm{P}_{\mathrm{I}}$ and $\mathrm{P}_{\mathrm{K}}$ increased from 14.71 and $9.81 \mu M$ to 16.03 and $11.19 \mu M$, respectively, after incubation at $\mathrm{pH} 2.0$ and $37^{\circ} \mathrm{C}$ for $4 \mathrm{~h}$. The $\mathrm{IC}_{50}$ value of peptide $\mathrm{P}_{\mathrm{P}}$ also increased significantly, but the extent of increase was less than that of peptides $\mathrm{P}_{\mathrm{I}}$ and $\mathrm{P}_{\mathrm{K}}$ peptides $(P<0.05)$. After treatment at $\mathrm{pH} 10$, the ACE inhibitory activity of peptide $\mathrm{P}_{\mathrm{K}}$ was very significantly $(P<0.01)$ degraded. Moreover, the $\mathrm{IC}_{50}$ value of peptide $\mathrm{P}_{\mathrm{I}}$ decreased significantly $(P<0.05)$ and that of peptide $\mathrm{P}_{\mathrm{P}}$ increased significantly $(P<0.05)$. This phenomenon could be the result of some small peptides with higher ACE inhibitory activities being released when the peptides were incubated at $\mathrm{pH} 10$.

The results of the $\mathrm{ACE}$ test showed that the $\mathrm{IC}_{50}$ value of ACE inhibitory peptides $\mathrm{P}_{\mathrm{I}}, \mathrm{P}_{\mathrm{K}}, \mathrm{P}_{\mathrm{M}}$, and $\mathrm{P}_{\mathrm{P}}$ did not change significantly before and after incubation with ACE $(P<0.05$; Figure 2). It also demonstrated that these 4 peptides were true ACE inhibitors.

Koumiss is a natural fermented dairy product and its microbial composition is much more complex than that of other commercial fermented dairy products. Many extracellular enzymes are excreted by various microbes found in koumiss. Some microbial cells of koumiss are lysed under high acid conditions ( $\mathrm{pH} 3.5$ ) and could release many cell-wall components and protein or peptide substances such as intracellular enzymes. Presently, very little is known about the nitrogen composition of koumiss. Its therapeutic properties may originate from its abundant bioactive protein/peptides and microbial content.

The structure-activity relationship of ACE inhibitory peptides from food proteins has not been studied in depth to date. However, some general features have been reported (FitzGerald et al., 2004). Angiotensin Iconverting enzyme inhibitory peptides usually contain 2 to 12 amino acids, and the 3 novel ACE inhibitory peptides $\mathrm{P}_{\mathrm{K}}, \mathrm{P}_{\mathrm{M}}$, and $\mathrm{P}_{\mathrm{P}}$ identified in this study have sequences in agreement with this earlier finding. However, ACE inhibitory peptide $\mathrm{P}_{\mathrm{I}}$ is different. This result is similar to that of Yamamoto et al. (1994): in their study on ACE inhibitory peptides, they found active peptides with up to 27 amino acids. Gobbetti et al. (2000) noted that ACE-inhibitory peptides derived from caseins contained a high proportion of hydrophobic peptides $(>60 \%)$. In accordance with that result, peptides $\mathrm{P}_{\mathrm{I}}$ and $\mathrm{P}_{\mathrm{M}}$ had more than $60 \%$ hydrophobic amino acid residues in their amino acid composition.

\section{CONCLUSIONS}

The ACE inhibitory activity of koumiss was not affected by ACE preincubation but it improved greatly after digestion by gastrointestinal proteases pepsin, trypsinase, and chymotrypsin. This indicated that the inhibitors were of the pro-drug type or a mixture of the pro-drug type and the true inhibitor type. Our present results demonstrated that koumiss had high 

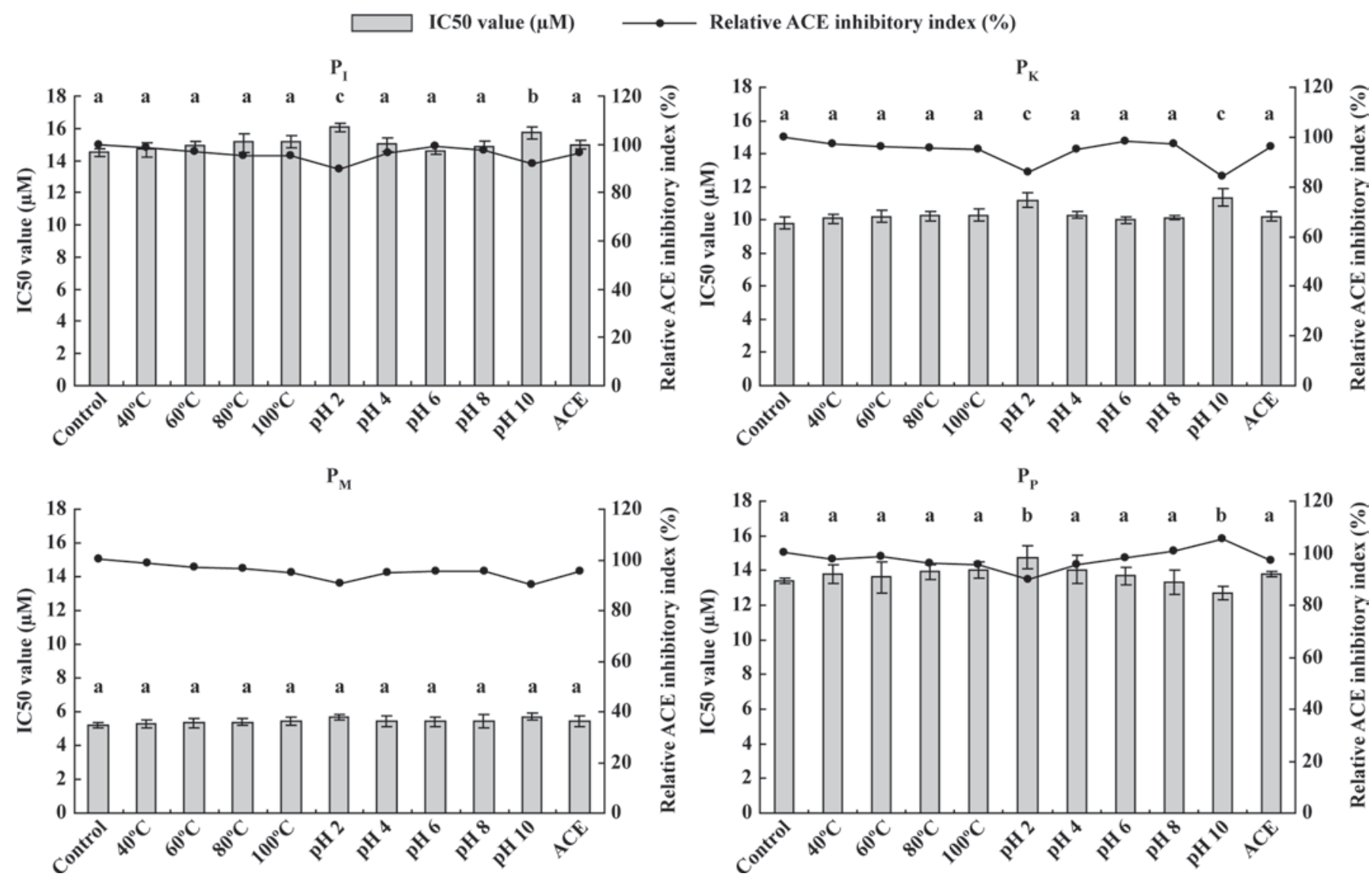

Figure 2. Stability of angiotensin I-converting enzyme (ACE) inhibitory peptides $\mathrm{P}_{\mathrm{I}}, \mathrm{P}_{\mathrm{K}}, \mathrm{P}_{\mathrm{M}}$, and $\mathrm{P}_{\mathrm{P}}$ derived from koumiss incubated at various temperatures, $\mathrm{pH}$, and $\mathrm{ACE}$ treatments for $2 \mathrm{~h}$. The relative ACE inhibitory percentage was calculated as the ratio of ACE inhibitory activity between the control and the treatments (relative $\mathrm{ACE}$ inhibitory index $=50 \%$ inhibitory concentration $\left(\mathrm{IC}_{50}\right)$ value of samples/ $\mathrm{IC}_{50}$ value of control $\times 100 \%)$. ${ }^{\mathrm{a}-\mathrm{c}}$ Means bearing different letters in the same row differ significantly compared with control samples $(P<0.05)$.

ACE-inhibitory activity; the MW of the high active fraction was $<3 \mathrm{kDa}$. Four peptides $\left(\mathrm{P}_{\mathrm{I}}, \mathrm{P}_{\mathrm{K}}, \mathrm{P}_{\mathrm{M}}\right.$, and $\mathrm{P}_{\mathrm{P}}$ ) with $\mathrm{MW}$ of $2,995.5,792.6,871.5$, and 1,460.7 Da, respectively, were purified from this high-activity fraction. Their amino acid sequences were YQDPRLGPTGELDPATQPIVAVHNPVIV, PKDLREN, LLLAHLL, and NHRNRMMDHVH, respectively. Peptide $\mathrm{P}_{\mathrm{I}}$ was considered part of $\beta$-casein (f213-241) in mare's milk; peptide $\mathrm{P}_{\mathrm{K}}$ corresponded to f144-150 of cytochrome ctype protein NrfB. The other 2 peptides, $\mathrm{P}_{\mathrm{M}}$ and $\mathrm{P}_{\mathrm{P}}$, did not correspond to any milk protein or peptides reported in the NCBI database. Moreover, all 4 peptides were true ACE inhibitors. The ACE inhibitory activity of koumiss makes it commercially attractive in the future as a health-enhancing ingredient in the production of functional foods. The studies on in vivo antihypertensive activity of active koumiss peptides and their functional mechanisms are currently in progress in our laboratory.

\section{ACKNOWLEDGMENTS}

This research was supported by Hi-tech Research and Development Program of China (863 Program; grant nos. 2006AA10Z345 and 2007AA10Z353).

\section{REFERENCES}

Ana, Q., M. Ramos, B. Muguerza, M. A. Delgado, M. Miguel, A. Aleixandre, and I. Recio. 2007. Identification of novel antihypertensive peptides in milk fermented with Enterococcus faecalis. Int. Dairy J. 17:33-41.

AOAC. 1997. Official Methods of Analysis. 17th ed. Association of Official Analytical Chemists, Washington, DC.

Centeno, J. M., M. C. Burguete, M. Castello-Ruiz, M. Enrique, S. Valles, J. B. Salom, G. Torregrosa, J. F. Marcos, E. Alborch, and P. Manzanares. 2006. Lactoferricin-related peptides with inhibitory effects on ACE-dependent vasoconstriction. J. Agric. Food Chem. 54:5323-5329.

Cheung, H. S., F. L. Wang, M. A. Ondetti, E. F. Sabo, and D. W. Cushman. 1980. Binding of peptide substrates and inhibitors of angiotensin-converting enzyme. Importance of the $\mathrm{COOH}$-terminal dipeptide sequence. J. Biol. Chem. 255:401-407. 
Church, F. C., H. E. Swaisgood, D. H. Porter, and G. L. Catignani. 1983. Spectrophotometric assay using o-phthaldialdehyde for determination of proteolysis in milk and isolated milk proteins. J. Dairy Sci. 66:1219-1227.

Csapo-Kiss, Z., J. Stefler, T. G. Martin, S. Makray, and J. Csapó. 1995. Composition of mares' colostrum and milk. Protein content, amino acid composition and contents of macro and micro-elements. Int. Dairy J. 5:403-415.

Cushman, D. W., H. S. Cheung, E. F. Sabo, and M. A. Ondetti. 1977. Design of potent competitive inhibitors of angiotensin converting enzyme. Carboxyalkanoyl and mercapto alkanoyl amino acids. Biochemistry 16:5484-5491.

Di Cagno, R., A. Tamborrino, G. Gallo, C. Leone, M. D. Angelis, M. Faccia, P. Amirante, and M. Gobbetti. 2004. Uses of mares' milk in manufacture of fermented milks. Int. Dairy J. 14:767-775.

Fitz Gerald, R. J., B. A. Murray, and D. J. Walsh. 2004. Hypotensive peptides from milk proteins. J. Nutr. 134:980S-988S.

Fujita, H., K. Yokoyama, and M. Yoshikawa. 2000. Classification and antihypertensive activity of angiotensin I-converting enzyme inhibitory peptides derived from food proteins. J. Food Sci. 65:564-569.

Geerlings, A., I. C. Villar, F. H. Zarco, M. Sánchez, R. Vera, A. Z. Gomez, J. Boza, and J. Duarte. 2006. Identification and characterization of novel angiotensin-converting enzyme inhibitors obtained from goat milk. J. Dairy Sci. 89:3326-3335.

Gobbetti, M., P. Ferranti, E. Smacchi, F. Goffredi, and F. Addeo. 2000. Production of Angiotensin-I-converting-enzyme-inhibitory peptides in fermented milks started by Lactobacillus delbrueckii ssp. bulgaricus SS1 and Lactococcus lactis subsp. cremoris FT4. Appl. Environ. Microbiol. 60:3898-3904.

Guo, B. 2003. Bacteria in Yogurt. Yogurt. Chemical Industry Press, Beijing, China.

Ishii, S. 2003. Study on the koumiss (Airag) of Mongolian nomads after severe cold in the winters of 2000 and 2001. Milk Sci. 52:49-52.

Lamoureux, L., D. Roy, and S. F. Gauthier. 2002. Production of oligosaccharides in yogurt containing bifidobacteria and yogurt cultures. J. Dairy Sci. 85:1058-1069.

López-Fandiňoa, R., J. Otteb, and J. van Camp. 2006. Physiological, chemical and technological aspects of milk-protein-derived peptides with antihypertensive and ACE-inhibitory activity. Int. Dairy J. 16:1277-1293.

Malacarne, M., F. Martuzzi, A. Summer, and P. Mariani. 2002. Protein and fat composition of mare's milk: Some nutritional remarks with reference to human and cow's milk. Int. Dairy J. 12:869-877.
Mao, X. Y., J. R. Ni, W. L. Sun, P. P. Hao, and L. Fan. 2007 Value-added utilization of yak milk casein for the production of angiotensin-I-converting enzyme inhibitory peptides. Food Chem. 103:1282-1287.

Marconi, E., and G. Panfili. 1998. Chemical composition and nutritional properties of commercial products of mare milk powder. J. Food Compost. Anal. 11:178-187.

Mullin, W. J., and D. B. Emmons. 1997. Determination of organic acids and sugars in cheese, milk and whey by high performance liquid chromatography. Food Res. Int. 30:147-151.

Ozer, B. 2000. Fermented milks. Products of Eastern Europe and Asia. Pages 803-804 in Encyclopedia of Food Microbiology. R. K. Robinson, C. A. Batt, and P. D. Patel, ed. Academic Press, London, UK.

Qi, S. 1986. Mineral determination. Direction on Animal Biochemistry Experiment (In Chinese). Agriculture Press of China, Beijing.

Riordan, J. F. 2003. Angiotensin-I-converting enzyme and its relatives. Genome Biol. 4:225.

Studdy, P. R., R. Lapworth, and R. Bird. 1983. Angiotensin-converting enzyme and its clinical significance: A review. J. Clin. Pathol. 36:938-947.

Sun, T., Menhebilige, J. Wang, Y. Chen, D. Zhao, and H. Zhang. 2005. Analysis of chemical composition and microorganism flora of traditionally home-made Koumiss in Xinjiang. Chin. Dairy Indust. 33:9-13. (In Chinese).

Wang, J., X. Chen, W. Liu, M. Yang, Airidengcaicike, and H. Zhang. 2008. Identification of Lactobacillus from Koumiss by conventional and molecular methods. Eur. Food Res. Technol. 227:15551561 .

Wu, H., G. Tang, and Y. Wang. 1996. Determination of vitamins in brown rice by HPLC. Chin. J. Chromatogr. 14:140-141. (In Chinese).

Yamamoto, N., A. Akino, and T. Takano. 1994. Antihypertensive effect of the peptides derived from casein by an extracellular proteinase from Lactobacillus helveticus CP790. J. Dairy Sci. 77:917-922

Yuan, Q., S. Zhao, Wuyungaowa, and Muergen. 2006. Clinical observation on koumiss treatment of coronary heart disease (sixtytwo cases). Med. World China 12:111-112. (In Chinese).

Zhang, J. H., E. Tatsumi, C. H. Ding, and L. T. Li. 2006. Angiotensin I-converting enzyme inhibitory peptides in douchi, a Chinese traditional fermented soybean product. Food Chem. 98:551-557. 